\title{
In vitro antioxidative activity of yellow tea and its in vivo preventive effect on gastric injury
}

\author{
QIANG WANG* ${ }^{*}$ XIN ZHAO*, YU QIAN and RUI WANG \\ Department of Biological and Chemical Engineering, Chongqing University of Education, Chongqing 400067, P.R. China
}

Received February 11, 2013; Accepted May 7, 2013

DOI: $10.3892 /$ etm.2013.1117

\begin{abstract}
Yellow tea is a traditional Chinese drink widely used in Asia. The aim of this study was to determine the antioxidant activity of yellow tea and its preventive effect on gastric injury. The antioxidant effects were determined by measuring the 1,1-diphenyl-2-picryhydrazyl (DPPH) free radical- and hydroxyl radical-scavenging activity. The yellow tea extract demonstrated high antioxidant activity in the assays of DPPH and hydroxyl radical-scavenging activity. Additionally, an animal model was used to investigate the preventive effect of yellow tea on gastric injury. High concentrations of yellow tea reduced the levels of the serum pro-inflammatory cytokines interleukin (IL)- 6 and tumor necrosis factor (TNF)- $\alpha$ to a greater extent than low concentrations. The extent of the gastric injury was significantly reduced by yellow tea, which demonstrated its anti-inflammatory properties. Yellow tea demonstrated the strongest inhibitory effect $(74.6 \%)$ against gastric injury when administered at a dose of $1,000 \mathrm{mg} / \mathrm{kg}$ by gavage. These results suggest that yellow tea possesses good antioxidant activity and a preventive effect on gastric injury in vivo.
\end{abstract}

\section{Introduction}

Yellow tea is a rare type of tea, which is slowly gaining recognition in Western countries. It is produced only in China and has a long history of use (1). Yellow tea usually implies a special tea processed similarly to green tea; however, it has a slower drying phase, where the damp tea leaves are allowed to sit and become yellow. This color is acquired by adding an extra step during production, called 'sealed yellowing', which is a slow oxidation process of tea polyphenols, including catechin (2).

Correspondence to: Dr Xin Zhao, Department of Biological and Chemical Engineering, Chongqing University of Education, 9 Xuefu Main Street, Nan'an, Chongqing 400067, P.R. China

E-mail: zhaoxin@pusan.ac.kr

*Contributed equally

Key words: yellow tea, antioxidant, Sprague-Dawley rat, cytokine, gastric injury
This unique step causes the tea to mellow and become bright yellow in color, without the grassy taste of green tea.

Antioxidants are substances that protect cells from damage caused by free radicals. Free radicals are molecules that have lost an electron and are therefore unstable (3). These free radicals take electrons from other molecules in order to stabilize themselves, ultimately creating new free radicals in the process. The removal of electrons may cause damage to DNA and lead to the possible development of inflammation (4).

Gastric injury is an injury to the stomach. It may be blunt or penetrating and may involve damage to the stomach organs. Ethanol promotes the rapid formation of injuries in the stomach, which occurs mainly due to an inflammatory reaction (5). Ethanol-induced gastric injury is characterized by epithelial cellular loss, mucosal edema and subepithelial hemorrhage (6). Cytokines, including interleukin (IL)-6 and tumor necrosis factor (TNF)- $\alpha$, are small proteins that are produced and released from a number of cells under physiological and pathological conditions (7). IL-6 is increasingly recognized as an almost ubiquitous participant in numerous types of inflammatory processes (8). TNF- $\alpha$ is a macrophage-derived cytokine with chemotactic potency, which has been implicated in the acute phase reaction under various inflammatory conditions (9).

In the current study, the antioxidant activity of yellow tea and its preventive effect on gastric injury were examined. 1,1-Diphenyl-2-picryhydrazyl (DPPH) free radical- and hydroxyl $(\mathrm{OH})$ radical-scavenging assays were conducted to evaluate the antioxidant activity of yellow tea. Additionally, measurements of the levels of the inflammation-related cytokines IL- 6 and TNF- $\alpha$ were used to determine the preventive effects of yellow tea on $\mathrm{HCl} /$ ethanol-induced gastric injury in Sprague-Dawley rats.

\section{Materials and methods}

Preparations of yellow tea. Yellow tea was purchased from Sichuan Mengding Huangcha Tea Industry Co., Ltd., China. The yellow tea was stored at $-80^{\circ} \mathrm{C}$ and freeze-dried to produce a powder. A twenty-fold volume of boiling water was added to the powdered sample and extraction was conducted twice. The aqueous extract was evaporated using a rotary evaporator (Eyela N-1100, Tokyo, Japan), concentrated and then dissolved in dimethylsulfoxide (DMSO; Amresco, Solon, OH, USA) to adjust to the stock concentration $(20 \%, \mathrm{w} / \mathrm{v})$. 
DPPH free radical assay. The DPPH free radical-scavenging activity was determined according to the method of Blois (10). Four milliliters of 100, 200 and $500 \mu \mathrm{g} / \mathrm{ml}$ concentrations of the sample solution were added to $1.0 \mathrm{ml}$ DPPH methanol solution $\left(1.5 \times 10^{-4} \mathrm{M}\right)$. After storing at room temperature for 30 mins, the absorbance of the solution was determined at $520 \mathrm{~nm}$ using a spectrophotometer and the remaining DPPH was quantified. The results expressed are the means of triplicate values (11).

$\mathrm{OH}$ radical assay. The $\mathrm{OH}$ radical-scavenging activity was assessed as described by Banerijee et al (12). The reaction system $(1.4 \mathrm{ml})$, contained yellow tea extract, deoxyribose $(6 \mathrm{mM}, 0.2 \mathrm{ml}), 0.2 \mathrm{ml}$ sodium phosphate buffer solution (20 mM, pH 7.4), $0.2 \mathrm{ml}$ anhydrous iron chloride $\left(\mathrm{FeCl}_{3}\right.$; $400 \mu \mathrm{M}), 0.2 \mathrm{ml} \mathrm{FeSO}$-ethylenediaminetetraacetic acid (EDTA; $400 \mu \mathrm{M}), 0.2 \mathrm{ml} \mathrm{H}_{2} \mathrm{O}_{2}(3 \mathrm{mM}), 0.2 \mathrm{ml}$ ascorbic acid $(400 \mu \mathrm{M})$ and $0.2 \mathrm{ml}$ yellow tea extract solution (50, 100 and $200 \mu \mathrm{g} / \mathrm{ml}$ ). After incubation at $37^{\circ} \mathrm{C}$ in a water bath for $60 \mathrm{~min}$, the reaction was stopped by adding $1 \mathrm{ml}$ trichloroacetic acid and $1 \mathrm{ml}$ 2-thiobarbituric acid in a 1.4-ml reaction system. The solution was boiled for $20-25 \mathrm{~min}$ at $90^{\circ} \mathrm{C}$ in a water bath. The absorbance was measured at $532 \mathrm{~nm}$. All analyses were run in triplicate and averaged.

Animals. Male Sprague-Dawley rats ( $\mathrm{n}=50,7$-weeks-old) were purchased from the Experimental Animal Center of Chongqing Medical University (Chongqing, China). The rats were maintained in a temperature-controlled facility (temperature, $25 \pm 2^{\circ} \mathrm{C}$; relative humidity, $50 \pm 5 \%$ ) with a 12 -h light/dark cycle and free access to a standard rat chow diet and water.

Gastric injury assay. The experimental design was as follows: the normal and control groups received 14-day repeated oral administration of distilled water and a single dose of the vehicle $(2 \mathrm{ml} / \mathrm{kg}$ b.w. olive oil, p.o.); the sample groups received 14-day repeated oral administration of 250, 500 or $1,000 \mathrm{mg} / \mathrm{kg}$ yellow tea extract. Then, the control and sample group rats were administered $1 \mathrm{ml} \mathrm{HCl} /$ ethanol $(60 \%$ in $150 \mathrm{mM} \mathrm{HCl}$ ) p.o. through esophageal intubation and were then sacrificed $1 \mathrm{~h}$ later under deep ether anesthesia. The stomachs were removed, inflated by injecting $10 \mathrm{ml} 1 \%$ formalin for $10 \mathrm{~min}$ to fix the tissue walls and opened along the greater curvature. The area $\left(\mathrm{mm}^{2}\right)$ of hemorrhagic lesions developed in the stomach was measured using a digital camera (D550; Canon, Tokyo, Japan) with a square grid and the images were analyzed by ImageJ software (National Institutes of Health, Bethesda, MD, USA). These experiments followed a protocol approved by the Animal Ethics Committee of Chongqing Medical University (Chongqing, China).

Analysis of inflammation-related cytokines in serum by enzyme-linked immunosorbent assay (ELISA). For the serum cytokine assay, blood from the inferior vena cava was collected in a tube and centrifuged $\left(1,370 \mathrm{x}\right.$ g for $10 \mathrm{~min}$ at $\left.4^{\circ} \mathrm{C}\right)$. The serum was aspirated and assayed as follows: Concentrations of the inflammatory-related cytokines IL-6 and TNF- $\alpha$ in serum were measured by ELISA according to the kit manufacturer's instructions (BioLegend, San Diego, CA, USA). Briefly, after the biotinylated antibody reagent was added to 96-well plates,

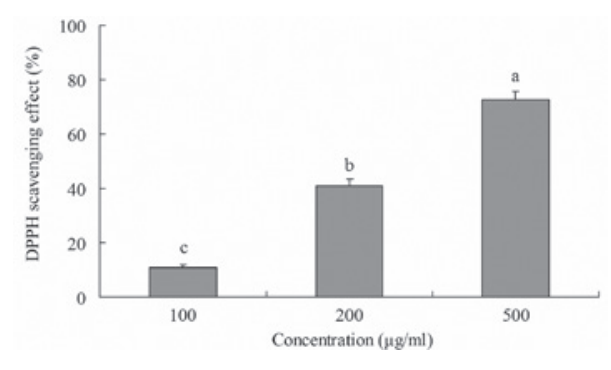

Figure 1. 1,1-Diphenyl-2-picryhydrazyl (DPPH) free radical-scavenging activity of yellow tea. ${ }^{\mathrm{a}, \mathrm{b}, \mathrm{c}}$ Mean values with different letters over the bars are significantly different $(\mathrm{P}<0.05)$ according to Duncan's multiple range test.

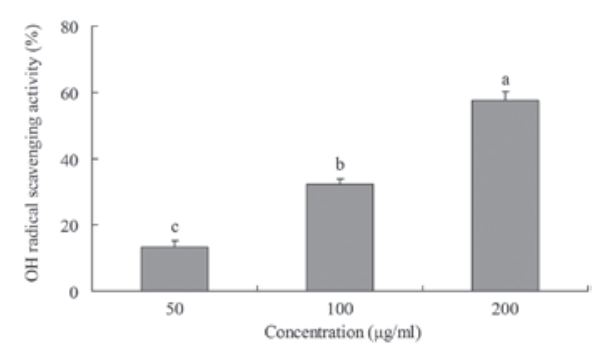

Figure 2. Hydroxyl radical-scavenging activity of yellow tea. ${ }^{\mathrm{a}, \mathrm{b}, \mathrm{c}}$ Mean values with different letters over the bars are significantly different $(\mathrm{P}<0.05)$ according to Duncan's multiple range test.

supernatants of homogenized serum were incubated at $37^{\circ} \mathrm{C}$ in $\mathrm{CO}_{2}$ for $2 \mathrm{~h}$. After washing with phosphate-buffered saline (PBS), horseradish peroxidase (HRP)-conjugated streptavidin peroxidase solution was added and the plate was incubated for $30 \mathrm{~min}$ at room temperature. The absorbance was then measured at $450 \mathrm{~nm}$ using a microplate reader (13).

Statistical analysis. Data are presented as mean \pm standard deviation (SD). Differences between the mean values for individual groups were assessed with one-way analysis of variance (ANOVA) with Duncan's multiple range test. $\mathrm{P}<0.05$ was considered to indicate a statistically significant difference. SAS version 9.1 (SAS Institute Inc., Cary, NC, USA) was used for statistical analyses.

\section{Results}

DPPH radical-scavenging activity. The radical-scavenging activity of yellow tea was investigated using DPPH radicals (Fig. 1). Yellow tea showed scavenging activity on DPPH radicals at various concentrations. At 100, 200 and $500 \mu \mathrm{g} / \mathrm{ml}$, the radical-scavenging activities were $10.8,41.0$ and $72.6 \%$, respectively. This indicates that the radical-scavenging activity of yellow tea increased as the concentration of its extract increased.

$\mathrm{OH}$ radical-scavenging activity. The ability of yellow tea to scavange $\mathrm{OH}$ radicals was evaluated by measuring the deoxyribose damage induced by the $\mathrm{Fe}^{3+} /$ ascorbate/EDTA/ $\mathrm{H}_{2} \mathrm{O}_{2}$ system using the thiobarbituric acid (TBA) method (14). Deoxyribose degrades into fragments that react with TBA upon heating at a low $\mathrm{pH}$ to form a pink color. The inhibitory effects of yellow tea on deoxyribose damage are shown in Fig. 2. The inhibitory rate of a $200 \mu \mathrm{g} / \mathrm{ml}$ extract was $57.6 \%$, which is higher than those of $100 \mu \mathrm{g} / \mathrm{ml}(32.2 \%)$ and $50 \mu \mathrm{g} / \mathrm{ml}(13.2 \%)$ extracts. 


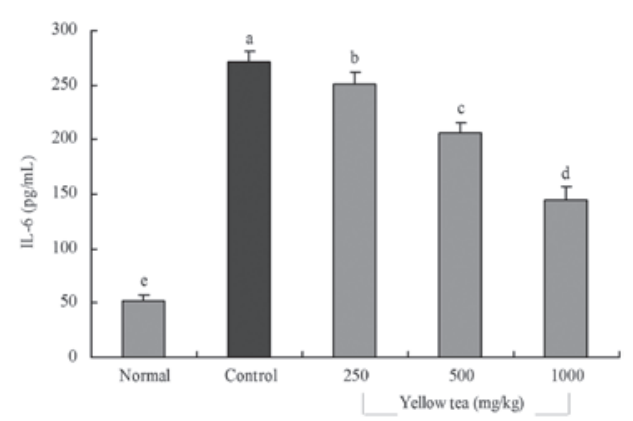

Figure 3. Effect of yellow tea on the serum interleukin (IL)-6 level in rats with $\mathrm{HCl} /$ ethanol-induced gastric injury. ${ }^{\mathrm{a}-\mathrm{e}} \mathrm{Mean}$ values with different letters over the bars are significantly different $(\mathrm{P}<0.05)$ according to Duncan's multiple range test.

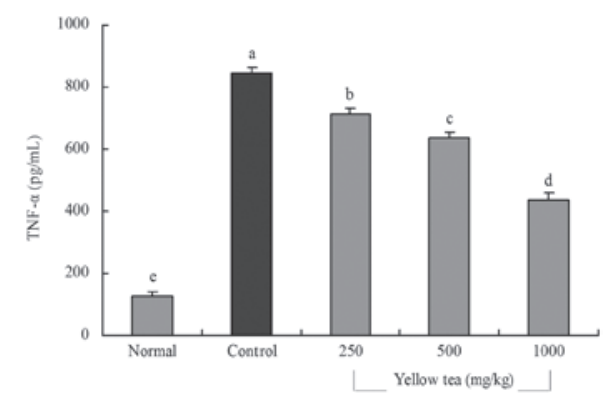

Figure 4. Effect of yellow tea on the serum tumor necrosis factor (TNF)- $\alpha$ level in rats with $\mathrm{HCl} /$ ethanol-induced gastric injury. ${ }^{\mathrm{a}-\mathrm{e}} \mathrm{Mean}$ values with different letters over the bars are significantly different $(\mathrm{P}<0.05)$ according to Duncan's multiple range test.

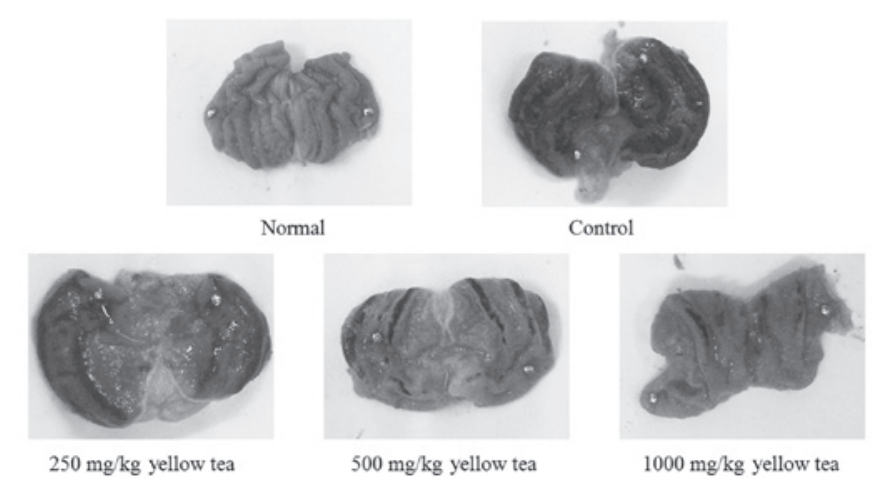

Figure 5. Appearance of the stomach following $\mathrm{HCl} /$ ethanol-induced gastric injury in rats treated with various concentrations of yellow tea.

Inflammation-related cytokine levels in serum. The IL-6 level of normal rats was $52.1 \pm 4.5 \mathrm{pg} / \mathrm{ml}$; however, that of control rats was significantly increased to $271.2 \pm 10.2 \mathrm{pg} / \mathrm{ml}$ following the induction of gastric injury. The levels of IL-6 in rats fed with 250,500 and $1,000 \mathrm{mg} / \mathrm{kg}$ yellow tea were $250.7 \pm 11.2,206.3 \pm 9.8$ and $144.3 \pm 12.2 \mathrm{pg} / \mathrm{ml}$, respectively (Fig. 3). The TNF- $\alpha$ levels in normal, control and 250, 500 and $1,000 \mathrm{mg} / \mathrm{kg}$ yellow tea-treated rats were $127.5 \pm 14.6$, $843.3 \pm 22.2,715.3 \pm 18.5,635.4 \pm 20.6$ and $438.4 \pm 19.4 \mathrm{pg} / \mathrm{ml}$, respectively (Fig. 4). The serum IL-6 and TNF- $\alpha$ levels in the rats in the yellow tea-treated groups were significantly lower than those in the control group.
Table I. Preventive effect of yellow tea treatment against $\mathrm{HCl} / \mathrm{ethanol-induced} \mathrm{gastric} \mathrm{injury.}$

\begin{tabular}{lcc}
\hline & \multicolumn{2}{c}{ Gastric injury data } \\
\cline { 2 - 3 } Group & Gastric injury $\left(\mathrm{mm}^{2}\right)$ & Inhibition rate (\%) \\
\hline Normal & $0.0 \pm 0.0^{\mathrm{c}}$ & 100.0 \\
Control & $14.2 \pm 3.4^{\mathrm{a}}$ & 0.0 \\
Yellow tea (mg/kg) & & \\
250 & $12.6 \pm 2.2^{\mathrm{c}}$ & 11.3 \\
500 & $6.2 \pm 1.6^{\mathrm{c}}$ & 56.3 \\
1000 & $3.6 \pm 1.1^{\mathrm{c}}$ & 74.6 \\
\hline
\end{tabular}

${ }^{\mathrm{a}-c}$ Mean values with different letters in the same column are significantly different $(\mathrm{P}<0.05)$ according to Duncan's multiple range test.

Gastric injury levels. The administration of yellow tea to rats prior to the induction of gastritis led to reduced gastric injury. The rats of the control group demonstrated a gastric injury area of $14.2 \pm 3.4 \mathrm{~mm}^{2}$. Treatment with 250 and $500 \mathrm{mg} / \mathrm{kg}$ yellow tea resulted in gastric injury inhibition rates of $11.3 \%$ (gastric injury area, $12.6 \pm 2.2 \mathrm{~mm}^{2}$ ) and $56.3 \%$ (gastric injury area, $6.2 \pm 1.6 \mathrm{~mm}^{2}$ ), respectively, while $1,000 \mathrm{mg} / \mathrm{kg}$ yellow tea (inhibition rate, $74.6 \%$; gastric injury area, $3.6 \pm 1.1 \mathrm{~mm}^{2}$ ) demonstrated the best gastritis preventive effect (Table I and Fig. 5). The results suggest that yellow tea has a strong preventive effect on gastric injury.

\section{Discussion}

Although yellow tea is a traditional drink, little scientific data on its effects are available. Yellow tea is a type of fermented tea. Since a large number of digestive enzymes are generated during its smothering process, a slow oxidation process, yellow tea is beneficial for the spleen and stomach. A previous study demonstrated that yellow tea, which is rich in tea polyphenols, polysaccharides, vitamins and amino acids, has special effects for preventing and curing esophageal cancer (2).

The DPPH assay is based on the capacity of a substance to scavenge stable radicals. It has been widely used to test the ability of compounds or plant extracts to act as free radical-scavengers or hydrogen donors (11). DPPH is a stable free radical (purple in color) which may accept an electron or hydrogen radical to become a stable yellow diamagnetic molecule. It is widely used to predict the potential antioxidative capability of foods and plant extracts in vitro. The highly reactive $\mathrm{OH}$ radical causes oxidative damage to DNA, proteins and lipids, which contribute to inflammation, mutagenesis and cytotoxicity (15).

The serum levels of cytokines, including IL-6, TNF- $\alpha$, IL-1 $\beta$ and interferon (IFN)- $\gamma$, in patients with inflammatory diseases are higher compared with those in healthy individuals (16). Thus, lower levels of IL-6 and TNF- $\alpha$ are indicative of anti-inflammatory effects and yellow tea demonstrates a good protective effect against gastric damage. Hepatocytes bear a variety of cytokine receptors. IL-6 is an interleukin that acts as a pro-inflammatory and anti-inflammatory cytokine. In humans, it is encoded by the IL-6 gene (17). IL-6 is secreted 
by $\mathrm{T}$ cells and macrophages to stimulate the immune response, particularly in the process of tissue damage leading to inflammation. IL-6 also plays a role in fighting infection (18). TNF- $\alpha$ is a cytokine involved in systemic inflammation and is a member of a group of cytokines that stimulate the acute phase reaction. The primary role of TNF- $\alpha$ is in the regulation of immune cells. TNF, as an endogenous pyrogen, is able to induce fever, induce apoptotic cell death, sepsis (through IL-1 and IL-6 production), cachexia and inflammation, as well as inhibit tumorigenesis and viral replication (19). The inflammatory cytokines IL- 6 and TNF- $\alpha$ play pathogenic roles in diseases of the stomach (20). Although systemic IL-6 levels are elevated following traumatic hemorrhage, hepatocellular function is impaired and gastric injury occurs (21). TNF- $\alpha$ is also a key mediator in a number of experimental models of stomach injury (22).

The current study demonstrates that yellow tea has antioxidant activity and is effective in the prevention of $\mathrm{HCl} /$ ethanol-induced gastric injury in Spraque-Dawley rats. Our results demonstrate that the protective effects of yellow tea may be due to its antioxidant activity and reductions in the levels of pro-inflammatory cytokines, including IL-6 and TNF- $\alpha$. The appearance of the stomach also indicated that yellow tea is able to prevent $\mathrm{HCl} /$ ethanol-induced gastric injury. These results suggest that yellow tea has in vitro antioxidant effects and is potentially useful in the treatment or prevention of chemical-induced gastric injury in vivo.

\section{Acknowledgements}

This study was supported by the Natural Science Foundation Project of CQ CSTC (No. CSTC2012jjA80002) and Supported by the Science and Technology Research Project of Chongqing Municipal Education Commission (No. KJ121504).

\section{References}

1. Zhou JR, Ni DJ, Chen YQ, Zhan XP and Yuan FT: Study on quality variation during the yellow tea processing. Hubei Nong Ye Ke Xue 43(1): 93-95, 2004 (In Chinese).

2. Zhao X: In vitro anticancer effect of yellow tea in HT-29 human colon cancer cells. Journal of Beijing Union University (Natural Sciences) 23(3): 11-13, 2009 (In Chinese).

3. Valko M, Rhodes CJ, Moncol J, Izakovic M and Mazur M: Free radicals, metals and antioxidants in oxidative stress-induced cancer. Chem Biol Interact 160: 1-40, 2006.

4. Collins AR: Oxidative DNA damage, antioxidants, and cancer. Bioessays 21: 238-246, 1999.
5. Szabo S, Trier JS, Brown A and Schnoor J: Early vascular injury and increased vascular permeability in gastric mucosal injury caused by ethanol in the rat. Gastroenterology 88: 228-236, 1985.

6. Medeiros JV, Gadelha GG, Lima SJ, Garcia JA, Soares PM, Santos AA, Brito GA, Ribeiro RA and Souza MH: Role of the NO/cGMP/KATP pathway in the protective effects of sildenafil against ethanol-induced gastric damage in rats. $\mathrm{Br} \mathrm{J}$ Pharmacol 153: 721-727, 2008.

7. Ramadori G. and Armbrust T: Cytokines in the liver. Eur J Gastroenterol Hepatol 13: 777-784, 2001.

8. McCurry KR, Campbell DA Jr, Scales WE, Warren JS and Remick DG: Tumor necrosis factor, interleukin 6, and the acute phase response following hepatic ischemia/reperfusion. J Surg Res 55: 49-54, 1993

9. Ming WJ, Bersani L and Mantovani A: Tumor necrosis factor is chemotactic for monocytes and polymorphonuclear leukocytes. J Immunol 138: 1469-1472, 1987.

10. Blois MS: Antioxidant determinations by the use of a stable free radical. Nature 181, 1199-1200, 1958.

11. Kang HS, Chung HY, Jung JH, Kang SS and Choi JS: Antioxidant effect of Salvia miltiorrhiza. Arch Pharm Res 20: 496-500, 1997.

12. Banerijee A, Dasgupta N and Bratati De: In vitro study of antioxidant activity of Syzygium cumini fruit. Food chem 90: 727-733, 2005

13. Park HS, Park JY and Yu R: Relationship of obesity and visceral adiposity with serum concentrations of CRP, TNF- $\alpha$ and IL-6. Diabetes Res Clin Pract 69: 29-35, 2005.

14. Gutteridge JM, Rowley DA, Griffiths E and Halliwell B: Low-molecular-weight iron complexes and oxygen radical reactions in idiopathic haemochromatosis. Clin Sci (Lond) 68: 463-467, 1985.

15. Uauy R, Hoffman DR, Peirano P, Birch DG and Birch EE: Essential fatty acid in visual and brain development. Lipids 36 : 885-895, 2001.

16. Gratacós J, Collado A, Filella X, Sanmartí R, Cañete J, Llena J, Molina R, Ballesta A and Muñoz-Gómez J: Serum cytokines (IL-6, TNF- $\alpha$, IL-1 $\beta$ and IFN- $\gamma$ ) in ankylosing spondylitis: a close correlation between serum IL-6 and disease activity and severity. Rheumatology 33: 927-931, 1994.

17. Ferguson-Smith AC, Chen YF, Newman MS, May LT, Sehgal PB and Ruddle FH: Regional localization of the interferon-beta 2/B-cell stimulatory factor $2 /$ hepatocyte stimulating factor gene to human chromosome 7p15-p21. Genomics 2: 203-208, 1988.

18. van der Poll T, Keogh CV, Guirao X, Buurman WA, Kopf M and Lowry SF: Interleukin-6 gene-deficient mice show impaired defense against pneumococcal pneumonia. J Infect Dis 176: 439-444, 1997.

19. Gosselin D and Rivest S: Role of IL-1 and TNF in the brain: twenty years of progress on a Dr. Jekyll/Mr. Hyde duality of the innate immune system. Brain Behav Immun 21: 281-289, 2007.

20. Abdollahi H, Shams S, Zahedi MJ, Moghadam SD, Hayatbakhsh MM and Jafarzadeh A: IL-10, TNF- $\alpha$ and IFN- $\gamma$ levels in serum and stomach mucosa of Helicobacter pylori-infected patients. Iran J Allergy Asthma Immunol 10: 267-271, 2011.

21. Gislason H, Røkke O and Svanes K: Release of cytokines associated with gastric mucosal injury. Eur Surg Res 28: 278-286, 1996.

22. Kuzuhara T, Suganuma M, Oka K and Fujiki H: DNA-binding activity of TNF-inducing protein from Helicobacter pylori. Biochem Biophys Res Commun 362: 805-810, 2007. 